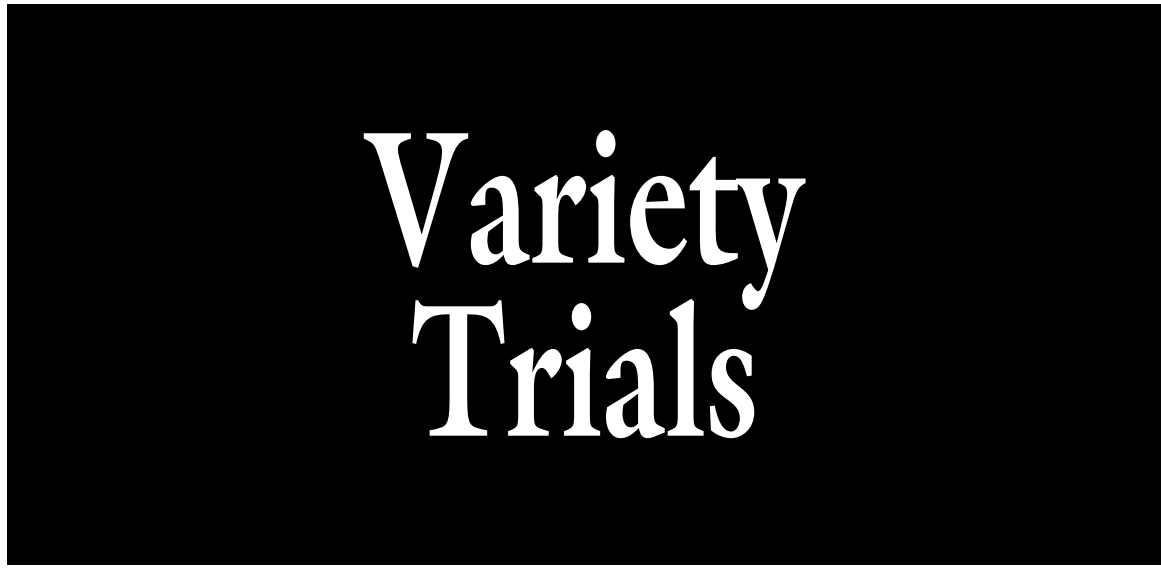

\section{Evaluation of Tomato Varieties under Organic Production Practices in Georgia}

\author{
George E. Boyhan ${ }^{1,4,8}$, Suzzanne Tate ${ }^{2,5}$, Ryan McNeill ${ }^{2,6}$, \\ and Jeffrey McConnaughey ${ }^{3,7}$
}

ADDITIONAL INDEX WORDs. certified organic production, determinate, $F_{1}$ hybrids, fresh market tomato, growth habit, indeterminate, National Organic Program, open-pollinated

\begin{abstract}
Summary. Tomato (Solanum lycopersicum) is a popular crop among organic growers, particularly open-pollinated varieties; however, there is a lack of information evaluating these varieties in comparison with commercial $F_{1}$ hybrids. This study was undertaken to compare conventionally produced commercial $\mathrm{F}_{1}$ tomato varieties available in the southeastern United States with open-pollinated varieties popular among organic growers. Nineteen tomato varieties were evaluated in 2011 and 2012 using the U.S. Department of Agriculture National Organic Program guidelines; however, the land used had not been in 3 years of organic production. Staked tomatoes were grown on plastic mulch. Data collected included early and total graded yield. In general, $F_{1}$ hybrid, determinate or semideterminate varieties, had the best early and total yields compared with open-pollinated varieties. HSX 8115H and 'Celebrity' had the highest early total yield. 'Costoluto Fiorentino', an open-pollinated variety, also had good early total yield, but significantly less than HSX $8115 \mathrm{H}$ or 'Celebrity'. 'Costoluto Fiorentino' was the only open-pollinated variety among the five highest yielding varieties for early total yield. In addition, 'Celebrity' had the greatest total yield of all the entries tested. All of the top five varieties for total yield were $F_{1}$ hybrids and either determinate or semideterminate types. 'Costoluto Fiorentino' had total yield of 22,046 lb/acre, which was $14.3 \%$ lower than the lowest yielding variety in the top five yielding varieties. 'Florida Pink' had the largest average fruit weight, which also had the lowest total yield of all the entries. Although the open-pollinated varieties, popular among organic and local growers, yielded less than $F_{1}$ hybrids, they may possess characteristics of color, flavor, or texture that are desired and were not evaluated in this study. This may be an opportunity for plant breeders to develop varieties desired by local organic growers that have unique characteristics, in addition to high yields and disease resistance.
\end{abstract}

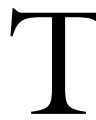
Tomato is an important crop in the United States with 105,700 acres of fresh tomatoes harvested and 327,800 acres of processed tomatoes valued at $\$ 2.5$ billion [U.S. Department of Agriculture (USDA), 2009]. In Georgia, tomato production is valued at $\$ 33.5$ million and is produced on 3400 acres (Wolf and Shepherd, 2012). required to register with the Georgia Department of Agriculture; however, they are not required to report acres and about half of the 124 certified organic farms did not report acreage. In addition, many growers do not obtain certification from the USDA or use an alternative certification such as Certified Naturally Grown (J. Gaskin, personal communication). Although it is impossible to ascertain the number of organic acres in Georgia, it is probably in the range of 4000-5000 acres. This increase in organic production has resulted in an increase in research efforts in this area; however, there continues to be a growing need for organic research that can help this agricultural sector.

Variety evaluation is one area that can be helpful for organic producers. Several such studies have been conducted by researchers around the world examining different aspects of variety performance under organic conditions. Organic variety evaluations have occurred in Italy, India, Spain, Croatia, Poland, France, and the United States (Campanelli et al., 2012; Francis and Stark, 2012; Ganesan, 2001; Gonzalez-Cebrino et al., 2011; Kapoulas et al., 2011; Piazza et al., 2003; Porteneuve et al., 2012; Ronga et al., 2011, 2012; Sánchez-Giráldez et al., 2012; Szafirowska, 2010). Along with yield, a number of other characteristics have been investigated including fruit cracking, antioxidants such as lycopene, sugar, and vitamin $\mathrm{C}$ content (Aldrich et al., 2010; Bender et al., 2005; Sánchez-Giráldez et al., 2012). There continues to be a need for variety evaluations as many of the available varieties are locally adapted or only regionally available. There has been little trialing of tomato varieties under organic conditions in the southeastern United States. One study in North Carolina evaluated heirloom and hybrid tomatoes in conjunction with various production practices including organic and conventional. The heirloom variety Stupice and the hybrid NC 0652 did well under organic production, whereas NC 0652 did better under conventional production (Davis, 2007).

Efforts to develop varieties specifically for organic production have been shown to be possible with wheat [Triticum asetivum (Murphy et al., 2007)]. In two of the five locations evaluated in this study, conventionally 
produced wheat yielded higher, while at the other three locations there was no difference in yield. However, there was a variety by production system (i.e., organic vs. conventional) interaction in four of the five locations suggesting that selection of phenotypes for organic production may be possible.

Breeding vegetables for organic production systems has been limited. Although there are many openpollinated vegetable varieties, most commercial varieties have been developed for conventional production with an emphasis on $F_{1}$ hybrids, which often exhibit hybrid vigor and protect the breeder's investment. Organic growers are interested in openpollinated varieties from which the seed can be easily saved. Most seed companies are reluctant to invest in such varieties because the seed of such varieties is so easily saved. Public breeding programs that filled this void by having a primary focus on developing open-pollinated varieties have been reduced over the years as resources have been diverted into biotechnology and basic research. For example, at Auburn University in the early 1980s, there were three plant breeders working on seven different horticultural crops. Today there are no plant breeders actively working on releasing new horticultural varieties at this institution. The National Association of Plant Breeders (NAPB) recommendations for improving germplasm lists fieldbased plant breeding capacities, second only to germplasm conservation as goals for the next 5 years (NAPB, 2011).

In a review article, Lammerts van Bueren et al. (2011) suggested several areas that should be emphasized in organic breeding programs. These included soil nutrient use efficiency, rhizosphere competence for disease resistance, weed competition, disease

\footnotetext{
${ }^{1}$ Department of Horticulture, University of Georgia, 1111 Miller Plant Science Building, Athens, GA 30602

${ }^{2}$ Durham Horticulture Farm, University of Georgia, 1221 Hog Mountain Road, Watkinsville, GA 30677

${ }^{3} 401$ College Circle, Athens, GA 30605

${ }^{4}$ Professor, Extension Horticulturist-Vegetables

${ }^{5}$ Horticulturist

${ }^{6}$ Farm Superintendent

${ }^{7}$ Former Graduate Student

${ }^{8}$ Corresponding author. E-mail: gboyhan@uga.edu.
}

resistance, insect resistance, abiotic stress tolerance, and quality.

There have been some collaborative efforts in breeding for organic production. An example is the Northern Organic Vegetable Improvement Collaborative that includes four universities, the USDA, and the Organic Seed Alliance (Oregon State University, 2013). This group has not only been active in breeding for organic production but maintains a database of organic variety trials.

As breeding efforts increase focusing on organic production, there will be an increasing need to evaluate these varieties. In addition, currently available open-pollinated tomato varieties that may be locally adapted, that have not been the focus of commercial production, will have to be evaluated. This study was undertaken to compare, under organic production practices, fresh market modern $\mathrm{F}_{1}$ varieties commonly grown in the southeastern United States with openpollinated varieties popular among organic growers.

\section{Materials and methods}

This study was conducted at the Durham Horticulture Farm in Watkinsville, GA (lat. $33^{\circ} 55^{\prime} \mathrm{N}$, long. $83^{\circ} 25^{\prime} \mathrm{W}$ ) on a Cecil sandy loam (Fine, kaolinitic, thermic Typic Kanhapludults) and included fresh market beefsteak-type tomato. In 2011, the experimental site was in year 2 of transition to National Organic Program (NOP) certified organic land. In 2012, the land used was not part of the NOP program and had been in conventional production before this study. In both cases, the land had not been in tomato production for at least the previous 10 years.

In 2011, untreated tomato seeds were sown in flats of organic media (Conrad Fafard, Agawam, MA) in a greenhouse on 10 Mar. 2011. In
2012 , untreated seeds were sown on 8 Mar. 2012. Seedlings were grown according to NOP guidelines (USDA, 2011 ) and University of Georgia Cooperative Extension Service recommendations for transplant production (Boyhan and Granberry, 2010). In 2011 , seedlings were fertilized with liquid fish + kelp (Neptune's Harvest, Gloucester, MA) by mixing 1 tablespoon per gallon of water. In 2012, a prepared media was used to produce the seedlings that included Fafard organic media, compost, worm castings, and perlite in about equal amounts. To this was added 3 cups/yard ${ }^{3}$ of kelp meal (Espoma Co., Millville, NJ), greensand (Fertrell Co., Bainbridge, PA), gypsum (Oldcastle Lawn \& Garden, Atlanta, GA), bonemeal (Voluntary Purchasing Group, Bonham, TX), and 1 cup/yard ${ }^{3}$ bloodmeal (Voluntary Purchasing Group).

In 2011 , the field was prepared with $120 \mathrm{lb} /$ acre nitrogen $(\mathrm{N})$, $14.4 \mathrm{lb} /$ acre phosphorus $(\mathrm{P})$, and $52.3 \mathrm{lb} /$ acre potassium $(\mathrm{K})$ by application of $8 \mathrm{~N}-2.2 \mathrm{P}-4.2 \mathrm{~K}$ (Nature Safe; Griffin Industries, Cold Springs, $\mathrm{KY}$ ) at a rate of $1500 \mathrm{lb} /$ acre applied preplant and incorporated on $25 \mathrm{Apr}$. 2011. In addition, 1 inch of compost was applied evenly over the entire site and incorporated. The compost used is produced at the University of Georgia with the primary feedstocks consisting of $60 \%$ from grounds and arbor operations and $25 \%$ from animal quarters bedding. The remainder is from various sources including paper, discarded bedding plants, and sod strips (D. Adams, personal communication). The compost has $\approx 1 \%$ of $\mathrm{N}, \mathrm{P}$, and $\mathrm{K}$. Beds, 6-ft on-center, were immediately formed and covered with 1-mil white on black plastic (Sigma Plastics Group, Lyndhurst, NJ) with a single drip irrigation line (8-inch emitter spacing, $0.2 \mathrm{gal} / \mathrm{h}$ at $10 \mathrm{psi}$ )

\begin{tabular}{llll}
\hline $\begin{array}{l}\text { Units } \\
\text { To convert U.S. to SI, } \\
\text { multiply by }\end{array}$ & U.S. unit & SI unit & $\begin{array}{l}\text { To convert SI to U.S., } \\
\text { multiply by }\end{array}$ \\
\hline 0.4047 & acre(s) & $\mathrm{ha}$ & 2.4711 \\
0.3094 & cup $(\mathrm{s}) / \mathrm{yard}^{3}$ & $\mathrm{~L} \cdot \mathrm{m}^{-3}$ & 3.2316 \\
0.3048 & $\mathrm{ft}$ & $\mathrm{m}$ & 3.2808 \\
3.7854 & $\mathrm{gal}$ & $\mathrm{L}$ & 0.2642 \\
2.54 & inch $(\mathrm{es})$ & $\mathrm{cm}$ & 0.3937 \\
1.1209 & $\mathrm{lb} / \mathrm{acre}$ & $\mathrm{kg} \cdot \mathrm{ha}^{-1}$ & 0.8922 \\
0.0254 & $\mathrm{mil}$ & $\mathrm{mm}$ & 39.3701 \\
28.3495 & $\mathrm{oz}$ & $\mathrm{g}$ & 0.0353 \\
6.8948 & $\mathrm{psi}$ & $\mathrm{kPa}$ & 0.1450 \\
3.9063 & tablespoon/gal & $\mathrm{mL} \cdot \mathrm{L}^{-1}$ & 0.2560
\end{tabular}


(Toro Micro-Irrigation, El Cajon, CA) under the plastic. The bed top was $\approx 3 \mathrm{ft}$ across. In 2012, the field was prepared with 158,73 , and $146 \mathrm{lb} /$ acre of $\mathrm{N}, \mathrm{P}$, and $\mathrm{K}$, respectively, applied as $13 \mathrm{~N}-0 \mathrm{P}-0 \mathrm{~K}$ (Nature Safe, Griffin Industries), bonemeal $(0 \mathrm{~N}-$ $4.4 \mathrm{P}-0 \mathrm{~K})$, and potassium sulfate $(0 \mathrm{~N}-$ 0P-43.2K) (SQM North America, Atlanta, GA), and 1 inch of compost. This was immediately incorporated on 12 Apr. 2012. Beds were formed and covered with white on black plastic (1 mil) with a single drip irrigation line under the plastic on 13 Apr. 2012.

There were 19 varieties arranged in a randomized complete block design with three replications. Local growers in Georgia recommended the open-pollinated varieties, whereas the $\mathrm{F}_{1}$ hybrids were varieties the respective seed companies were interested in having evaluated. Only the seed from Southern Exposure Seed Exchange (Acorn Community, VA), Seed Savers Exchange (Decorah, IA), and TomatoFest (Little River, CA) were organically produced. Each plot was $15 \mathrm{ft}$ long with a single row of plants with an in-row spacing of 1.5 $\mathrm{ft}$. The between-row spacing was $6 \mathrm{ft}$, and a 5 -ft in-row buffer separated individual plots. Plants were not pruned and 5 - $\mathrm{ft}$ wooden stakes were set in the soil between each plant. There was $\approx 4 \mathrm{ft}$ of stake aboveground after setting. Plants were supported by three courses of string, which were interwoven between the plants and stakes as the plants grew. Plants were scouted biweekly for insect and disease damage, but chemical management was not required. In 2011, liquid fertilizer was applied to the plants 6 weeks after transplanting with $4 \mathrm{~N}-1.3 \mathrm{P}-2.5 \mathrm{~K}$ (AgGrand, Superior, WI) applied with a 100:1 chemical injector (Dosatron International, Clearwater, FL) at $10 \mathrm{lb} /$ acre $\mathrm{N}$. Plants were irrigated as needed based on visual and tactile assessment of soil moisture.

Plants were assessed for growth habit just before first harvest. Each plot was assessed as either indeterminate, semideterminate, or determinate. Determinate plants did not grow taller than the stakes used. Semideterminate varieties grew $1-2 \mathrm{ft}$ beyond the top of the stake and indeterminate plants grew more than $2 \mathrm{ft}$ longer than the stakes. Vine ripe fruit were harvested on 12, 22, 26 July and 4, 11 Aug. 2011. Early yields were calculated as those fruit harvested on 12 and 22 July 2011. In 2012, fruit were harvested on 5, 10, $13,17,20,24,27$ July and 2, 10 Aug. Fruit harvested on 5-17 July 2012 were considered early. A Kerian Speed Sizer (Kerian Machines, Grafton, ND) was used to divide the ripe tomatoes into size classes. We divided the fruit into small/medium and large/extralarge size classes delineated by the maximum diameter opening a medium-sized fruit will pass through in any position (2-17/32 inches) (USDA, 1991). These size classes will henceforth be referred to as small and large, respectively. Only marketable fruit were graded and their yield recorded.

All data were transformed with a square root transformation to normalize the data and the final results were back transformed to their original units and yields are reported as pounds per acre. StataSE 12.1 (Stata Corp., College Station, TX) was used to calculate transformations, Fisher's protected least significant difference, and coefficients of variation.

\section{Results and discussion}

There was no variety $x$ year interaction for early total and total marketable yield, so the results from both years were combined (Table 1). HSX $8115 \mathrm{H}$ had the highest yield of total early fruit with $18,804 \mathrm{lb} /$ acre (Table $1)$. This yield was significantly higher than that of 'Costoluto Fiorentino', but did not differ from that of 'Celebrity'. The six top-yielding varieties for early total fruit were significantly greater than Scarlet Red, which had total early yield of $8361 \mathrm{lb} /$ acre. 'Mortgage Lifter VFN' and 'Florida Pink' had significantly lower total early yields compared with 14 of the varieties in the trial.

'Celebrity' had significantly greater total yield than all other entries in the trial with $33,574 \mathrm{lb} /$ acre (Table 1 ). The next highest total yield was produced by 'Mountain Fresh Plus' with $28,064 \mathrm{lb} /$ acre. It did not differ significantly from 'BHN 602' or 'Fletcher 0377'. Two open-pollinated varieties that had reasonably good total yield included Costoluto Fiorentino and Neptune with 22,046 and 15,436 $\mathrm{lb} / \mathrm{acre}$, respectively. Both of these open-pollinated varieties had significantly lower total yield than the top five yielding varieties.
The lowest total yielding variety was Florida Pink with $5077 \mathrm{lb} /$ acre. This variety had lower yields than any other variety in the trial with the exception of Jeff Davis with $6040 \mathrm{lb} /$ acre and Mortgage Lifter VFN with $7113 \mathrm{lb} /$ acre.

Fruit size averaged 5.8 oz compared with beefsteak tomato fruit, which are in the 6- to $10-\mathrm{oz}$ size (Jones, 2013). However, there were a few exceptions. 'Florida Pink' had the largest fruit compared with all other entries in the trial with an average fruit weight of $10.2 \mathrm{oz}$ (Table 1). 'Cherokee Purple' had the next largest average fruit size of $8.4 \mathrm{oz}$, which did not differ from 'Crnkovic Yugoslavian' or 'Mortgage Lifter VFN', but did differ significantly from all other entries.

The smallest average fruit size was with 'Neptune' at $3.0 \mathrm{oz} /$ fruit, which did not differ significantly from 'Ozark Pink' at $3.3 \mathrm{oz} /$ fruit or 'Druzba' at 4.3 $\mathrm{oz} /$ fruit. 'Neptune' fruit were smaller than all other entries in the trial.

Both large early yield and large total yield had a variety $\times$ year interaction, so these results were examined separately (Table 2 ). 'BHN 602' and 'Mountain Fresh Plus' had the greatest early large yield in 2011 with 3071 and $2877 \mathrm{lb} /$ acre, respectively. 'Scarlet Red' with $2212 \mathrm{lb} /$ acre had the third highest early large yield in 2011 and was significantly different from all other entries in the trial. Three entries had no early large fruit in 2011. They include 'Druzba', 'Costoluto Florentino', and 'Florida Pink'.

'BHN 602' and 'Mountain Fresh Plus' produced the greatest early large yield in 2012 with 8197 and $4037 \mathrm{lb} /$ acre, respectively (Table 2 ). 'Cherokee Purple' had the next highest early large yield in 2012 with $3075 \mathrm{lb} / \mathrm{acre}$, which did not differ significantly from that of 'Celebrity' with $2386 \mathrm{lb} / \mathrm{acre}$.

'Neptune' and 'Druzba' had no early large yield in 2012. 'Ozark Pink' had the lowest early large yield in 2012 with $77 \mathrm{lb} /$ acre. This variety did not differ significantly from 'Costoluto Fiorentino', 'Abraham Lincoln', 'Mortgage Lifter VFN', 'RFT 80772', and 'Florida Pink'.

'BHN 602' had the greatest total large yield in 2011 at $8082 \mathrm{lb} /$ acre, which was significantly more than all other varieties in 2011 (Table 2). That year, 'Mountain Fresh Plus' 
Table 1. Tomato variety trial with seed source, growth habit, variety type, and marketable (mkt.) yield grown under organic conditions in Spring and Summer 2011 and 2012.



${ }^{2}$ Seedway = Seedway Seed Co., Elizabethtown, PA; Harris Seed = Harris Seed Co., Rochester, NY; SESE = Southern Exposure Seed Exchange, Acorn Community, VA; Seed Savers $=$ Seed Savers Exchange, Decorah, IA; TomatoFest $=$ TomatoFest, Little River, CA; Rogers $/$ Syngenta = Syngenta US, Greensboro, NC; Harris Moran = Harris Moran Seed Co., Modesto, CA; Hortag = Hortag Seed Co., Chapel Hill, NC.

yEarly yield: 12, 21 July $2011 ; 5,10,13,17$ July 2012. Total yield: 12, 21, 26 July and 4, 11 Aug. 2011; 5, 10, 13, 17, 20, 24, 27 July and 2, 10 Aug. 2012.

${ }^{\mathrm{x}} \mathrm{l} \mathrm{lb} / \mathrm{acre}=1.1209 \mathrm{~kg} \cdot \mathrm{ha}^{-1}, \mathrm{l} \mathrm{oz}=28.3495 \mathrm{~g}, \mathrm{l}$ fruit $/$ acre $=2.471 \mathrm{l}$ fruit $/ \mathrm{ha}$.

wData for 2012 only.

'Fisher's protected least significant difference at $P \leq 0.05$.

produced $7000 \mathrm{lb} /$ acre of large fruit, more than any other variety except BHN 602. The third highest yielding variety in 2011 was Fletcher 0377, which also had yield that was greater than all other varieties except BHN 602 and Mountain Fresh Plus.

In 2012, 'BHN 602' again had the highest total large yield compared with the other varieties with $11,869 \mathrm{lb} /$ acre (Table 2). The next two entries with the highest total large yield in 2012 were 'Mountain Fresh Plus' and 'Florida Pink' with 6079 and 5543 $\mathrm{lb} /$ acre, respectively. These two entries had significantly higher total large yield compared with all the other entries with the exception of 'BHN 602'.

In 2012, 'Neptune' had no large fruit. Other entries with low total large yield in 2012 included 'Costoluto Fiorentino', 'Abraham Lincoln', 'Druzba', and 'Ozark Pink', all of which had less than $700 \mathrm{lb} / \mathrm{acre}$.
Trial entries were also evaluated by variety type, $\mathrm{F}_{1}$ hybrid or openpollinated, and by growth habit (determinate, indeterminate, or semideterminate) (Tables 3 and 4). There was a significant variety type $\times$ year interaction for variety type, so results were evaluated separately for each year. In $2011, \mathrm{~F}_{1}$ hybrids $(13,025 \mathrm{lb} /$ acre $)$ out-yielded open-pollinated varieties (7200 lb/acre). In 2012, $\mathrm{F}_{1}$ hybrids $(32,119 \mathrm{lb} /$ acre $)$ outperformed openpollinated varieties $(15,226 \mathrm{lb} /$ acre $)$.

There were also significant differences between growth habits (Table 4 ). Determinate varieties yielded better with $26,846 \mathrm{lb} /$ acre compared with indeterminate or semideterminate varieties. In addition, semideterminate entries with an average yield of 14,740 $\mathrm{lb} /$ acre yielded better than indeterminate entries with $9453 \mathrm{lb} /$ acre.

Early yields can be an important characteristic in a variety because earlier yields generally command higher prices. However, this may not be as important with tomato production for organic or local markets. Early yields were dominated by $\mathrm{F}_{1}$ hybrid varieties. The exception to this was 'Costoluto Fiorentino', which is an open-pollinated variety. 'Costoluto Fiorentino' is described by the seed company as an heirloom variety from the Tuscany region of Italy. This variety is also described as an indeterminate variety; however, in this study, we scored it as semideterminate.

Other early entries were all $F_{1}$ hybrids. The company did not put HSX $8115 \mathrm{H}$, an experimental hybrid from Hortag Seed (Chapel Hill, NC) forward as a commercial variety. ' $\mathrm{Ce}$ lebrity' is a popular $\mathrm{F}_{1}$ hybrid used in commercial staked tomato production. The company, Harris Seed, describes this variety as semideterminate because although it has a determinate 
Table 2. Tomato yield of early and total large fruit for each year in 2011 and 2012.

\begin{tabular}{|c|c|c|c|c|}
\hline \multirow[b]{2}{*}{ Entry } & \multicolumn{2}{|c|}{$\frac{\text { Early large yield }^{\mathrm{z}}}{(\mathrm{lb} / \text { acre })^{\mathrm{y}}}$} & \multicolumn{2}{|c|}{$\frac{\text { Total large yield }^{\mathrm{z}}}{\text { (lb/acre) }}$} \\
\hline & 2011 & 2012 & 2011 & 2012 \\
\hline Abraham Lincoln & $173^{x}$ & $255^{\mathrm{x}}$ & $269^{x}$ & $255^{\mathrm{x}}$ \\
\hline BHN 602 & 3,071 & 8,197 & 8,082 & 11,869 \\
\hline Celebrity & 716 & 2,386 & 1,675 & 3,107 \\
\hline Cherokee Purple & 213 & 3,075 & 329 & 4,259 \\
\hline Costoluto Fiorentino & 0 & 126 & 0 & 624 \\
\hline Crnkovic Yougoslavian & 891 & 1,678 & 891 & 2,109 \\
\hline Druzba & 0 & 0 & 0 & 81 \\
\hline Fletcher 0377 & 1,518 & 2,212 & 4,877 & 2,673 \\
\hline Florida Pink & 0 & 834 & 0 & 5,543 \\
\hline HMX $8847 \mathrm{~F}_{1}$ & 126 & 2,215 & 439 & 3,148 \\
\hline HSX $8115 \mathrm{H}$ & 1,280 & 1,199 & 1,845 & 1,199 \\
\hline Jeff Davis & 63 & 2,241 & 263 & 3,753 \\
\hline Mortgage Lifter VFN & 136 & 440 & 301 & 2,309 \\
\hline Mountain Fresh Plus & 2,877 & 4,037 & 7,000 & 6,079 \\
\hline Neptune & 499 & 0 & 833 & 0 \\
\hline Ozark Pink & 126 & 77 & 736 & 77 \\
\hline RFT 80771 & 332 & 1,041 & 744 & 2,870 \\
\hline RFT 80772 & 1,184 & 661 & 1,457 & 2,939 \\
\hline Scarlet Red & 2,212 & 1,028 & 2,643 & 2,218 \\
\hline Coefficient of variation & $61 \%$ & $54 \%$ & $46 \%$ & $45 \%$ \\
\hline $\operatorname{LSD}(P \leq 0.05)^{\mathrm{w}}$ & 446 & 785 & 791 & 1,057 \\
\hline
\end{tabular}

Table 3. Planned comparisons of variety type in an organic tomato trial with 19 entries in 2011 and 2012.

\begin{tabular}{|c|c|c|c|}
\hline \multirow{2}{*}{\multicolumn{2}{|c|}{ Type }} & 2011 & 2012 \\
\hline & & \multicolumn{2}{|c|}{ Total yield (lb/acre $)^{\mathrm{z}}$} \\
\hline $\mathrm{F}_{1}$ hybrid & & 13,025 & 32,119 \\
\hline Open-pollinated & & 7,200 & 15,226 \\
\hline \multicolumn{4}{|l|}{ Probability } \\
\hline Type & 0.126 & 0.000 & 0.000 \\
\hline Year & 0.002 & & \\
\hline Type $\times$ year & 0.037 & & \\
\hline
\end{tabular}

${ }^{2} 1 \mathrm{lb} / \mathrm{acre}=1.1209 \mathrm{~kg} \cdot \mathrm{ha}^{-1}$.

growth habit, it continues to produce fruit throughout the season. 'Mountain Fresh Plus' and 'Fletcher 0377' were two $\mathrm{F}_{1}$ varieties with good early yield developed at North Carolina State University Mountain Horticultural Crops Research and Extension Center in Mills River, NC. According to the seed company, 'Mountain Fresh Plus' has resistance to fusarium wilt (Fusarium oxysporum) races 1 and 2, verticillium (Verticillium albo-atrum), and tolerance to nematodes (Meloidogyne sp.). 'Fletcher 0377' has resistance to verticillium, nematodes, and tomato spotted wilt virus (TSWV).

Overall, high total yields were primarily with $\mathrm{F}_{1}$ hybrid types, determinate or semideterminate varieties. Entries with high total yield included the previously mentioned varieties $\mathrm{Ce}$ lebrity, Mountain Fresh Plus, HSX $8115 \mathrm{H}$, Fletcher 0377, and Costoluto Fiorentino. In addition, 'BHN 602' and 'Scarlet Red' had reasonably high yields. 'BHN 602', according to the seed company, was specifically developed for Florida growing conditions. It
Table 4. Planned comparisons of growth habit in an organic tomato trial with 19 entries, 2011-2012.

\begin{tabular}{lc}
\hline Growth habit & $\begin{array}{c}\text { Combined years } \\
\text { total yield } \\
(\mathbf{l b} / \mathbf{a c r e})^{\mathrm{z}}\end{array}$ \\
\hline Determinate & $26,846 \mathrm{a}^{\mathrm{y}}$ \\
Indeterminate & $9,453 \mathrm{c}$ \\
Semideterminate & $14,740 \mathrm{~b}$ \\
Probability & \\
Growth habit & 0.003 \\
Year & 0.002 \\
Growth habit $\times$ year & 0.818 \\
\hline
\end{tabular}

${ }^{z} 1 \mathrm{lb} /$ acre $=1.1209 \mathrm{~kg} \cdot \mathrm{ha}^{-1}$.

yields followed by the same letter are not significantly different by Fisher's protected least significant difference at $P \leq 0.05$.

has resistance to fusarium wilt races 1 , 2 , and 3, verticillium wilt, and TSWV. In both 2011 and 2012, $F_{1}$ hybrids outyielded open-pollinated varieties (Table 2 ). The $\mathrm{F}_{1}$ hybrids were either determinate or semideterminate and the open-pollinated varieties were primarily indeterminate or semideterminate with only one determinate entry. The cultural practices of staked tomato on plastic mulch may have worked against the openpollinated varieties because this type of production is specifically suited to determinate types. As the indeterminate tomato grew, it became more difficult to keep them trellised. If these plants had a more robust trellis system, they may have done better in terms of yield. The plants were not pruned, which affected trellising. It was felt that pruning the plants might bias the results. However, pruning is a cultural practice that is used with determinate types in staked tomato production. The indeterminate varieties, because of their growth habit, were not well supported late in the production season. In fact, in year 2 of the study, two severe thunderstorms caused some of the supporting stakes to collapse, which required additional stakes and string to support these plants. This resulted in additional work and difficulty harvesting these fruit. Indeterminate tomatoes are also known for their continued production once they reach maturity, unlike determinate tomato where they reach a set size, produce a flush of fruit and are finished. In year 1, fruit were harvested from 12 July to 11 Aug. and in 
year 2 they were harvested from 5 July to 10 Aug. $\approx 4$ and 5 weeks, respectively. This could have been extended for the indeterminate tomato, which can produce for a longer period (i.e., greenhouse production with indeterminate types); however, the total fruit yield is generally about the same on a per-plant basis.

All of the entries in the trial were red tomato varieties with the exception of Ozark Pink and Florida Pink, which were pink. According to the seed company, 'Ozark Pink' has resistance to fusarium wilt race 1 , verticillium wilt, blossom end rot, and cracking. 'Florida Pink', although described by the seed company as a pink variety, did not have the same pink coloration of Ozark Pink. 'Florida Pink' had the largest fruit of all the entries in the trial with deep suture lines radiating from the stem end. 'Cherokee Purple', which is supposed to have a darker distinctive coloration that borders on brown, did not exhibit this trait in this trial. In fact, it had uneven color development with shoulders that remained green and fruit that never developed the darker color characteristic of this variety.

The average fruit of $5.8 \mathrm{oz}$, which was lower than the average for beefsteak tomatoes, may have been due to the lack of pruning. Along with controlling plant shape and facilitating trellising, pruning also results in large fruit.

Three $\mathrm{F}_{1}$ hybrids that did not exhibit particularly high total yields included 'HMX $8847 \quad \mathrm{~F}_{1}$ ', 'RFT 80771', and 'RFT 80772'. 'HMX $8847 \mathrm{~F}_{1}$ ' has been released as 'Red Bounty', and no additional information is available at this time concerning 'RFT 80771' and 'RFT 80772' other than they were experimental lines from Syngenta (Greensboro, NC). Many of the open-pollinated varieties have interesting backstories described in the seed catalogs. Some of these varieties date back to the 19th and early 20th centuries. 'Mortgage Lifter VFN', according to the seed company, dates back to the 1930s when it was developed in West Virginia from several large fruited tomatoes. 'Cherokee Purple' is dated pre-1890 with a Cherokee Indian origin. 'Abraham Lincoln' was introduced in 1923 as a late maturing variety. Along with 'Costoluto Fiorentino' from Tuscany, Italy, 'Druzba' was introduced from
Bulgaria and 'Crnkovic Yugoslavian' was introduced by Yasha Crnkovic from Vojvodina, Serbia.

The by-year interactions were generally an indication of the magnitude of yield differences with tomato yields better in year 2 . There were some trends that were similar between the years even though the byyear interaction was significant. For example, both 'Mountain Fresh Plus' and 'BHN 602' had the greatest early large yield and total large yield in both years. There were notable exceptions to this, such as 'RFT 80772', which had early large yield of $1184 \mathrm{lb} /$ acre in 2011 and $661 \mathrm{lb} /$ acre in 2012 . Other varieties that had lower early large yield in year 2 included Neptune, Ozark Pink, and Scarlet Red. By-year interaction differences that reflected only differences in magnitude were also evident in the comparison of $F_{1}$ hybrids and open-pollinated varieties for total yield.

In conclusion, the $\mathrm{F}_{1}$ hybrid varieties did better than the open-pollinated varieties, which is not surprising since $\mathrm{F}_{1}$ hybrids often exhibit hybrid vigor. Overall, the $\mathrm{F}_{1}$ hybrids also had more uniform fruit. The open-pollinated varieties tended to have more fruit variation as would be expected. This is probably not an issue for retailfocused organic growers. Although not a focus of this study, disease resistance has been an important component in developing modern tomato varieties. This focus on disease resistance, as well as yield and fruit uniformity, has dramatically improved the tomato industry in the United States. Older open-pollinated varieties may offer interesting visual, textual, and flavor components that have not been the focus of modern breeding efforts. With the increase in the organic and local food markets, there may be areas in which plant breeding can focus to bring better disease resistance and yields to older varieties with unique characteristics. Combining the uniformity, high yields, and disease resistance of modern varieties with unique flavor, textual, and visual characteristics of older varieties could be the focus of new breeding efforts.

\section{Literature cited}

Aldrich, H.T., K. Salandanan, P. Kendall, M. Bunning, F. Stonaker, O. Külen, and
C. Stushnoff. 2010. Cultivar choice provides options for local production of organic and conventionally produced tomatoes with higher quality and antioxidant content. J. Sci. Food Agr. 90:25482555.

Bender, I., S. Vabrit, and M. Raudseping. 2005. Tomatisortide iõhenemiskindlus jõgeva sordiaretuse instituudi mahekatses aastatel 2001-2003. Trans. Estonian Agr. Univ. Agron. 220:120-122.

Boyhan, G.E. and D.M. Granberry. 2010. Commercial production of vegetable transplants. Univ. Georgia Coop. Ext. Serv. Bul. 1144.

Campanelli, G., V. Ferrari, M. Caioni, E. Piccinini, N. Acciarri, and F. Leteo. 2012. Pomodoro per il biologico: Varietà di oggi e di ieri. Informatore Agrario 68:48-50.

Davis, J. 2007. NC organic research and publications. 10 Dec. 2013. <http:// www.ces.ncsu.edu/fletcher/programs/ ncorganic/research/>.

Francis, P.B. and C.R. Stark, Jr. 2012. Heirloom tomato production in conventional and transitional-organic managed systems. HortScience 47:1034-1037.

Ganesan, M. 2001. Performance of tomato (Lycopersicon esculentum Mill.) varieties under organic farming in greenhouse and open field conditions during winter season of Tamil Nadu. Madras Agr. J. 88:726-727.

Gonzalez-Cebrino, F., M. Lozano, M.C. Ayuso, M.J. Bernalte, M.C. Vidal-Aragon, and D. Gonzalez-Gomez. 2011. Characterization of traditional tomato varieties grown in organic conditions. Span. J. Agr. Res. 9:444-452.

Jones, J.B. 2013. Growing tomatoes-Fruit characteristics. 15 Oct. 2013. <http:// www.growtomatoes.com/tomato-fruitcharacteristics $>$.

Kapoulas, N., Z.S. Ilic, M. Durovka, R. Trajkovic, and L. Milenkovic. 2011. Effect of organic and conventional production practices on nutritional value and antioxidant activity of tomatoes. Afr. J. Biotechnol. 10:15938-15945.

Lammerts van Bueren, E.T., S.S. Jones, L. Tamm, K.M. Murphy, J.R. Myers, C. Leifert, and M.M. Messmer. 2011. The need to breed crop varieties suitable for organic farming, using wheat, tomato and broccoli as examples: A review. NJAS Wageningen. J. Life Sci. 58:193-205.

Murphy, K.M., K.G. Campbell, S.R. Lyon, and S.S. Jones. 2007. Evidence of varietal adaptation to organic farming systems. Field Crops Res. 102:172177. 
National Association of Plant Breeders. 2011. NAPB Recommendation for USDA/ARS germplasm improvement NP301 goals for the next 5 years. 18 Feb. 2014. <http://www.plantbreeding.org/ napb/Publications/NAPB\%20Policy/ USDAarsNP301.html>.

Oregon State University. 2013. Northern organic vegetable improvement collaborative (NOVIC). 10 Dec. 2013. <http:// eorganic.info/group/575l $>$.

Piazza, C., M. Conti, R. Reggiani, and L.D. Re. 2003. Prove varietali su pomodoro da industria in coltivazione biologica. Sementi Elette 49:35-38.

Porteneuve, C., F. Rey, C. Mazollier, and M. Marle. 2012. Criblage des variétés de légumes en agriculture biologique: Dixième année d'évaluation. Infos-Ctifl 287:24-30

Ronga, D., M. Zaccardelli, D. Perrone, C. Piazza, F. Colombani, F. Salamone,
M.T. Azzimonti, and B. Campion. 2012. Pomodoro da industria, varietà convenzionali in coltivazione biologica. Informatore Agrario 68:53-57.

Ronga, D., M. Zaccardelli, D. Perrone, G. Ragosta, C. Piazza, F. Colombani, F. Salomone, and B. Campion. 2011. Pomodoro da industria: Le varietà adatte al bio. Informatore Agrario 67:37-41.

Sánchez-Giráldez, H., M. Ramos, E. Zambrana, J.L. Tenorio, C.l. Cuadra, and I. Martín. 2012. Traditional and commercial tomato cultivars evaluation for organic horticulture in two regions of Spain, Caceres and Madrid. Acta Hort. 933:53-60.

Szafirowska, A. 2010. Ocena plonowania kilku odmian pomidora w uprawie ekologicznej. J. Res. Appl. Agr. Eng. 55:131-134.

U.S. Department of Agriculture. 1991. United States standards for grades of fresh tomatoes. 21 Aug. 2013. <http:// www.ams.usda.gov/AMSvl.0/ freshmarketvegetablestandards $>$.

U.S. Department of Agriculture. 2008. USDA ERS - Organic production. 16 Aug. 2013. <http://www.ers.usda.gov/dataproducts/organic-production.aspx\#25762>.

U.S. Department of Agriculture. 2009. Economics, statistics, and market information system. 16 Aug. 2013. <http:// usda.mannlib.cornell.edu/MannUsda/ viewDocumentInfo.do?documentID = $1210>$.

U.S. Department of Agriculture. 2011. Agricultural Marketing Service - National Organic Program. 19 July 2011. <http://www.ams.usda.gov/AMSvl.0/ NOPNationalOrganicProgramHome $>$.

Wolf, K. and T. Shepherd. 2012. 2011 Georgia farm gate value report. Univ. Georgia Rpt. AR-12-01. 